\title{
シンポジウム ウイルス性気道
}

\section{急性ウイルス性呼吸器疾患とその症状}

\section{Immunocytologic Finding of Nasal Epithelial Cells in Influenza}

Isao Ebisawa, M.D.

Dept. of Medicine, Inst. of Medical Science, the Univ. of Tokyo.

Nasal epithelial cells of influen:a patients stained with fluorescent antibody show following features. The localization of antigen is intranuclear, both intranuclear and intracytoplasmic, or intracytoplasmic according to the stage of cellular infection with influenza virus. The ciliated border of the cylindrical epithelial cell fluoresced very strongly throughout the second and the third stages of cellular infection. In addition to this, basal, intermediate, and mucus cells appeared to be infected by the influenza virus. The distribution of infected epithelial cells was not homogenous or diffuse, but isolated cells were infected in some areas, However, continuous cells were also infected in other areas.

1 . ヒトの急性呼吸器疾患をおこす病原体の種

\section{類と数}

ヒトの急性気道感染症をおこす病原体は大部 分がウイルスであり，その数が多いことが特有 である。表 1 は Chanock (1970) の表を少し変 えたものである。ここで注目すべき点はミクソ ウイルス, コロナウイルス, ライノウイルスは すべて急性呼吸器感染症をおこすことがしられ ている。しかし Coxsackie, アデノウイルス等 はそれぞれ29型中10型, 30型中 8 型が気道感染 症と関係があり, 他は気道感染を起すことは知 られていない。しかしそれでも 119 の病原体が 気道疾患をおこすことがわかつている。

その他に $\mathrm{ECHO}$, ハシカ, 水痘, ヘルペス ウイルス等, また本症の研究中しばしば問題に なるものとして肺炎ミコプラズマ, 溶連菌等が 病原的役割を演ずることも忘れてはならない。

2. 臨床的に特徽的な気道疾患, 侵襲部位と起 因ウイルス

各病原体の種類, 患者の年令, 基礎疾患の有

*東大医科研内科
表 1 ヒトの呼吸器疾患をおこす病原体

\begin{tabular}{|c|c|c|}
\hline ウイル ス & 型の 数 & $\begin{array}{l}\text { 気道疾患を } \\
お こ す\end{array}$ \\
\hline \multicolumn{3}{|l|}{ ミクソウイルス } \\
\hline インフルェンザ & 3 & $3(2)$ \\
\hline パラインフルエンザ & 4 & 4 \\
\hline R S & 1 & 1 \\
\hline コロナウイルス & $\geqq 3$ & 3 \\
\hline \multicolumn{3}{|l|}{ ピコルナウイルス } \\
\hline Coxackie A \& B & 29 & 10 \\
\hline ライノ & $\geqq 90$ & $\geqq 90$ \\
\hline アデノウイルス & 30 & 8 \\
\hline 計 & $\geqq 160$ & $\geqq 119$ \\
\hline
\end{tabular}

その他 $\mathrm{ECHO}$, ハシカ, 水痘, ヘルペスウイル ス, 肺炎ミコプラズマ, (溶連菌)

(Chanock, 1970)

無とその種類によって，その症状に差はある が，一般的な人が感染した場合には多少は特徵 的なニュアンスがある。

以下にはその最も特徵的な症状をのべる。病 変ないし，患者の訴えも表記（表2）の場所に 
気食会報一 23 巻

表 2 臨床的に特徵ある疾患, 主病巣と 起因ウイルス

\begin{tabular}{|c|c|c|}
\hline 部 位 & 疾 & 病＼cjkstart原 \\
\hline 目 & $\begin{array}{l}\text { EKC } \\
\text { PCF }\end{array}$ & $\begin{array}{l}\text { アデノ }(8 \text { 型 }) \\
\text { アデノ }(3,7, \cdots)\end{array}$ \\
\hline 鼻 & 鼻かぜ, 寒冒 & ライノ \\
\hline 咽 頭 & $\begin{array}{l}\text { ヘルパンギーナ } \\
\mathrm{PCF}\end{array}$ & $\begin{array}{l}\text { コクサッキーA } \\
\text { アデノ }(3,7, \cdots)\end{array}$ \\
\hline 喉 頭 & クループ & $\begin{array}{l}\mathrm{RS}, \text { アデノ } \\
\text { パラインフルエンザ }\end{array}$ \\
\hline 管 & 気管炎 & RS, インフルエンザ \\
\hline 気管支 & 気管支炎 & パラインフルエンザ \\
\hline 肺 & 肺＼cjkstart炎 & アデノ \\
\hline
\end{tabular}

限つたものでない事を銘記すべきである。例え ばライノウイルスによる鼻かぜあるいは普通感 冒ではかなり強い，何ともいえない不快な全身 症状を伴い，亜急性期には気管，気管枝炎を合 併しやすい事は多くの人が経験するところであ る。

主として眼あるいは眼と咽頭に病変のみられ る疾患がアデノウイルスによつておきる。前者 は EKC, 流行性角結膜炎で 8 型アデノウイル スによりおこる。後者は PCF, 咽頭結膜熱で 3， 7 型等のアデ/ウイルスによっておこる。

鼻に主な症状のあらわれるものとしては鼻か ぜ, あるいは普通感冒があり, その代表的病原 体はライノウイルスである。

咽頭に主病巣があるものにへルパンギーナと 咽頭結膜熱がある。前者は $\mathrm{A}$ 型コクサッキービ ールスによっておこる。

喉頭の病巣が前面にでる疾患としてクループ があり， RS，アデノ，パラインフルエンザウイ ルス等が主として関倸する。

気管炎, 気管枝炎, 肺炎等の病原体としては RS, インフルェンザ，パラインフルエンザ，ア デノウイルス等があげられる。

上述の記載は多分に観念的, シェーマ的なも のであり，検討の余地がのこされている。これ については後でこの報告の主題としてとりあげ たいと思う。

3. 同じ種類のウイルスによる異つた病型
呼吸器症状をおこすウイルスについて，特に 注目すべき点は同じ仲間の病原体が全く異つた 病状を呈することである。例えばアデノウイル スを例にとると（表 3 ), 本ウイルス感染が, 感冒様症状, 軽い上気道炎あるいは急性呼吸哑 疾患 (A.R.D) として分類されている急道症状 を呈することはよく知られている。

これに反し，PCF（咽頭結膜熱）はまだ近 の疾患として容易に理解されるが，流行性角愁 膜炎, 腸重積症, 腸間膜リンハ腺炎, 出血性腃 胱炎もアデ/ウイルスによっておこりらること は奇異に感じさせることである。

アデノウイルスはこの点, はなはだ特徴的な ウイルスであるが，コクサッキー A， B 群ウィ ルス, ECHOウイルスでも同じようなことがい える。

表 3 同じグループのウイルスによる異つ た症状一アデノウイルス群

\begin{tabular}{l|l}
\multicolumn{1}{c|}{ 臨 床 病 型 } & \multicolumn{1}{|c}{ 型 } \\
\hline URI 上気道炎 & $1,2,3,4,5,7,7 \mathrm{a}, 14$ \\
ARD 急性呼吸器疾患 & $3,4,7,7 \mathrm{a}, 14,21$ \\
Pneumonia 肺炎 & $1,2,3,4,7,7 \mathrm{a}, 18$ \\
PCF 咽頭結膜熱 & $1,3,4,7,7 \mathrm{a}, 14$ \\
EKC 流行性角結膜炎 & $8,(3,7)$ \\
かんとん & $1,2,3,5,6,7$ \\
腸管膜リン八腺炎 & $1,2,3,5,6$ \\
出血性膀胱炎 & 11 \\
\hline
\end{tabular}

4. 年令による罹患ウイルスの差

呼吸器ウイルスの種類と罹患年令を考えると 一つの特徵的な傾向に気づく。すなわち(表 4)

(i) 主として小児が罹患するウイルス

$\mathrm{RS}$, ，ーンフルェンザ, 水痘, 八シカウイ ルスなとで抗原性に変化がないことが第一の特 徵である。しかもそれぞれのウイルスの型が 1 つしかないか, 亜型が少数(4)に限られている ことが第 2 の特徴である。病像は異るが天然痘 流行地における同ウイルスもこのカテゴリーに 入る。

(ii) 主として小児が罹患するが若年の成人も 罹患する。

アデノ,コクサッキー, ECHOウイルスなど 
表 4 羅患年令とウイルスの性状

\begin{tabular}{|c|c|c|c|}
\hline 罹患年令 & ウイルス & 抗原性 & 型 \\
\hline$\underset{\text { 小として児 }}{\text { 主 }}$ & $\begin{array}{l}\mathrm{R} \mathrm{S} \\
\text { パラインフルエンザ } \\
\text { 水痘, ハシカ }\end{array}$ & 不変 & $\begin{array}{c}1 \\
\text { 少ない } \\
1\end{array}$ \\
\hline $\begin{array}{l}\text { 主として小 } \\
\text { 尜据よ゙若 } \\
\text { 成人 }\end{array}$ & $\begin{array}{l}\text { アデノ } \\
\text { コクサッキー } \\
\mathrm{ECHO}\end{array}$ & 不変 & 多、 $\left(\begin{array}{c}(32) \\
\begin{array}{l}A 23 \\
B\end{array} \\
>28\end{array}\right)$ \\
\hline 主に成人 & ライノ & 不変 & 多い(>55) \\
\hline $\begin{array}{l}\text { 機会あれば } \\
\text { 全年令層 }\end{array}$ & インフルエンザ & 変る & 少ない \\
\hline
\end{tabular}

で, この群のウイルスの特徵は, 個々のウイル スの抗原性に変化はないが, 型が多いことが特 有である。

(iii) 主として成人が䧹患するもの

ライノウイルスが代表的で，個々のウイルス の抗原性は変らないが，抗原の型が多いことが 特徴で，この 2 点は(ii)群のウイルスと全く同じ である。何故ライノウイルスは主として成人の み䍜患するか不明である。詳細にしらべればお そらく小児も頻繁に罹患しているかも知れな い。

(iv) 機会があれば全年令層が罹患するもの

インフルエンザウイルスが代表的でこのウイ

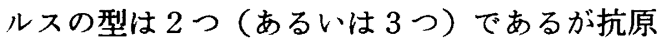
性が変りやすい事が特徴的である。従つて同じ A型ウイルスによっても反覆感染がおこる。ま た抗原性が大きな変化をとげると全年令層が感 受性をもつようになるため汎流行を来しうるこ とも説明がつく。

表 5 は1965年のA 2 型インフルエンザ患者の 発病初期における 3 つの A 2 型インフルエンザ ウイルスに対する HI 抗体を示す。

18人の $\mathrm{HI}$ 抗体の平均值は $1957 ， 1964$ 年度の 分離株に対してはそれぞれ229，148と高い値を 示している。すなわちかなり高い抵抗力がつい ている。しかし1965年の流行株に対しては21と いう低い值一すなわちほとんど免疫がないと いう事を示している。すなわちこの表に示した 1965年度のインフルェンザA 2 患者は1957ある いはそれ以後1964年までのA 2 型インフルエン ザウイルスに感染した明らかな証拠があるにか
表 51965 年インフルエンザA 2 患者急性期血 液の1957，1964，1965年分離インフルエ ンザA 2 株に対する HI抗体

\begin{tabular}{l|r|r|r}
\hline ウイルス株 & $\begin{array}{l}\mathrm{A} 2 / \text { 足立 } \\
/ 2 / 57\end{array}$ & $\begin{array}{l}\mathrm{A} 2 / 4 / 64 \\
/ 4 / 64\end{array}$ & $\begin{array}{r}\mathrm{A} 2 / \text { 態本 } \\
/ 1 / 65\end{array}$ \\
\hline 患 者 数 & 18 & 18 & 18 \\
平 均 $\mathrm{HI}$ 值 & 229 & 148 & 21 \\
$\mathrm{HI}$ 值 \\
の $\% 128$ の者
\end{tabular}

かわらず，1965年度の流行で再感染しているわ けである。1968年のホンコン型A 2 ウイルスに いたつてはさらに大きな抗原性の変化がおきた ためこのウイルスが全世界で広く流行したこと は周知のとおりである。

5. 研究テーマとしての呼吸器ウイルス病一呼 吸器ウイルスの侵入門戸, 初期定着部位, 細 胞内および組織内ウイルスの拡がり一臨床的 にインフルエンザを例にとると，

a).全身型発病

ある時期を界にして急に悪寒, 発熱等の全身 症状をもつてはじまる病型がある。喛はあつて も少ないかほとんどない。後になつて咳が出る 事もある。全身の筋肉痛, 関節痛, 腰痛等がは げしい。元気な人があたかも丸太で打ちのめさ れたように衰弱する。しかも後日採血した血清 でインフルェンザウイルスに対する有意の抗体 上昇が証明される。

b ) 局所症状 $\rightarrow$ 下降型発病

後鼻腔などに乾燥感, 疼痛等を訴え多少全身 の違和感がある。次に鼻閉, 鼻汁, 咽頭痛, な どあり次いであるいは平行して咳，前胸部痛， 喀痰等が出て来る。いかも病変が鼻咽腔にはじ まり，咽喉頭より気管の方に下つて来た症状で ある。

実験方法やその条件によっても異るが，マウ スにおける実験で感染が鼻より下降性に拡がる というデータと，まゔ肺胞細胞に感染し，上向 性に進展して最後になつて鼻腔細胞が感染する というデータがある。

このことは急性期インフルェンザ患者につい て前述の a ), b ) 型の発病型式を考えると合点 のゆくことである。また螢光抗体法を用いてあ る程度の推察をすることもできる。人体内であ る組織細胞内のインフルェンザウイルス感染の 
気食会報一 23 巻

有無をしらべるのに溃光抗体法はきわめて便利 である。鼻腔粘膜上皮細胞はポータブルの 鼻鏡々綿棒を用いて簡単にとることができるの でインフレエンザの発生病理をしらべる上で便 利である(図1)。

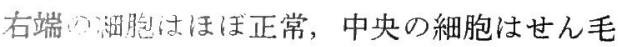
がその起始部と共に今にも脱落しそうである。

せん毛岏冠のようなものから生えているよう にみえる。核の上方に原形質突起が見える。左 端の細胞からはせん毛が脱落している。

5ー $\mathrm{a}$ ヒトの呼吸器上皮細胞内に扔けるイ ンフルエンザウイルスの拡がり

組織培養細胞におけるインフルエンザウイル スの生成過程とインフルエンザ患者の鼻粘膜上 皮細胞内インフルェンザウイルス抗原の分布を 考えると, 少なくともせん毛上皮細胞内ではイ ンフルエンザウイルスは次の様な段階を一て増 殖するもようである。(図 2,3 )

侵入場所………不明

抗原の出現部位…(i) 核

(ii)核のまわりとせん毛起始
跑 1 䕗糙膜せ九毛上皮細胞

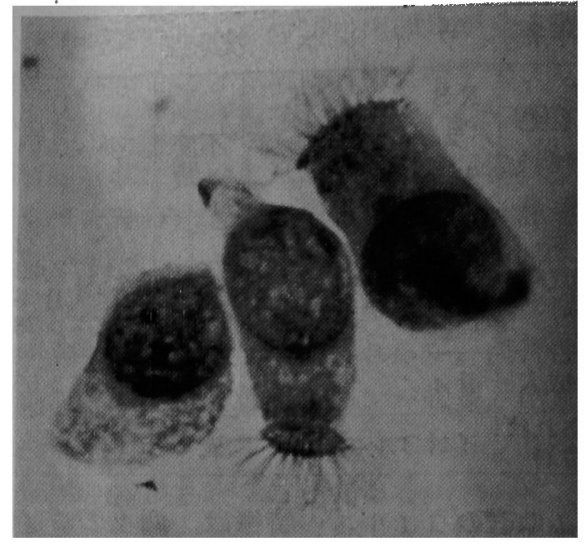

部

(iii)核，原形質，とくにせれ 毛起始部

(iv) 原形質

(v)せん毛起始部

(iv)(v)の時期になると細胞は変性, 脱落してしま うようである。

図 2 鼻粘膜にある上皮細胞の種類（左端）とせん毛上皮細胞内（右端）インフルエンザ ウイルス抗原の存在部位（黒、部分）

\section{Normal epithelium}

\section{Distribution of antigen}
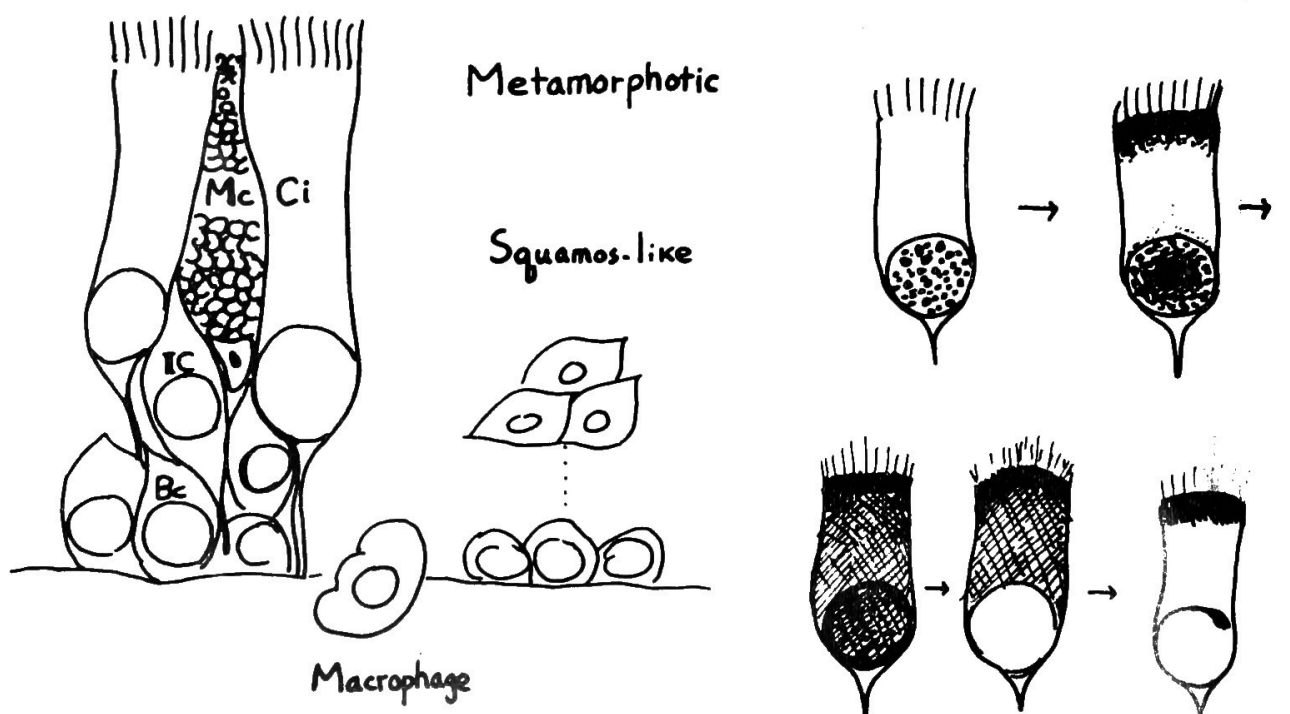

$\mathrm{Bc}=$ basal cell, $\mathrm{Ci}=$ Ciliated epithelial cell, $\mathrm{Ic}=$ intermediate cell, $\mathrm{Mc}=$ mucous or goblet cel

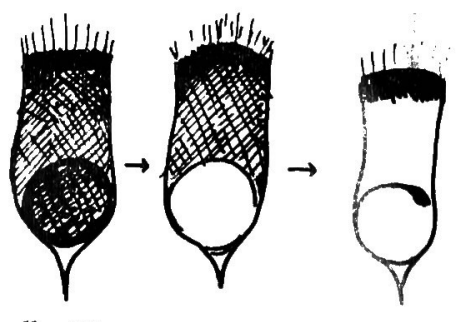


図 3 インフルエンザの特異䖝光を示す 鼻粘膜せん毛上皮細胞 (A 2 ホン コン型患者）

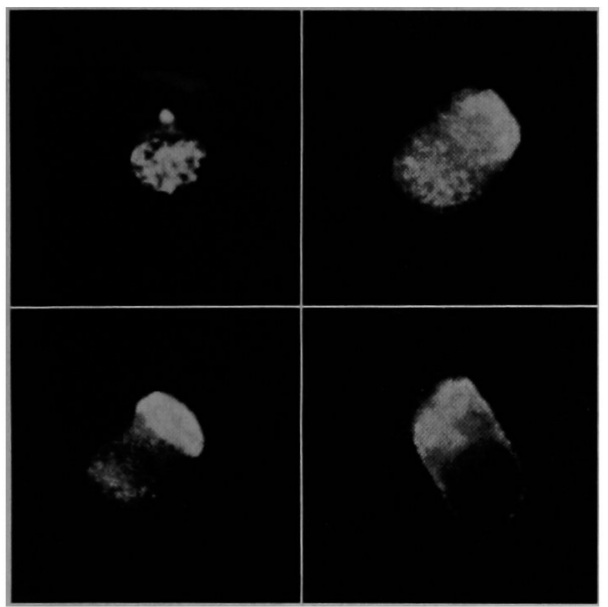

上左：核が強く, せん毛起始部が弱く光る 上右：細胞全体が光る

下左：せん毛起始部が強く，核が弱く光る

下右：原形質が光り核は光らない

以上はせん毛上皮細胞についてのべたが，そ の他の呼吸器粘膜上皮細胞（鼻粘膜では中間細 胞, 基底細胞等）についても同様の経過をとる ものと考えられる。

$5-b$ 鼻粘膜上皮内における感染細胞の分 布

急性期インフルエンザ患者の鼻粘膜上皮を多 数の例について観察するといくつかの異つた所 見に遭遇する。

(i) 全身型発病例で鼻粘膜細胞の感染が証明 されなかつたもの。

全身症状が強い割には咳などの呼吸器症状が 少ない例で鼻粘膜の充血が非常に強い例があつ た。かなりていねいに鼻粘膜細胞をとり，数枚 のスライドをつくつてたんねんにしらべたが感 染細胞をみつけることができなかつた例があ る。しかも血清反応ではまぎれもないインフル エンザであつた。この例では発病 $2 \sim 3$ 日目に 1 回しかしらべてないのでその後に鼻粘膜細胞 が感染したか否か不明である。いうれにしても このような例はむしろ上向性型の発病をしたも のではないかと考えられる。

5 -c 鼻粘膜細胞多数感染型症例
鼻粘膜塗抹標本で多数の感染細胞が証明され る例がある。ある例では一つの標本の直径約 $1 \mathrm{~cm}$ の円内に 350 以上もの感染細胞が証明され た。この様な例では鼻粘膜細胞のほとんどすべ てがインフルエンザウイルスの感染を受けてい る印象を受ける。鼻粘膜細胞を連続的にとつた 標本をみるとインフルエンザウイルスに感染し た細胞が連続的に数個数えられる場合がある。 他方同一人から同時にとつた標本で16個の細胞 中 1 個しか感染してない所もある。例えば中甲 介一つをとつても無数の上皮細胞があるわけで あるから，たとえ全体としては平等に充血腫脹 していても以上の標本が示すようにインフルエ ンザウイルスに感染した細胞はあまり多くない のかも知れない。この所見は実験的に感染させ たマウスの肺においても証明することができ る。

以上の所見はインフルエンザ肺炎の剖検例で 充血のひどい気管や気管枝粘膜の擦過塗抹標本 でインフルェンザウイルス感染細胞が案外証明 しにくい事と一致する。

\section{考 按}

以上我々は呼吸器ウイルス病の代表的なイン フルェンザについて，このウイルスにより撰択 的におかされる呼吸器系上皮細胞の代表として 鼻粘膜上皮細胞のインフルエンザウイル ス感染 の状況をうべた。

すなわち細胞内における同ウイルスの感染の 進展状況, 粘膜上皮組織内の感染細胞の分布等 について子れた。

これはヒトにおけるインフルエンザウイルス 感染症のごく一部をのぞいただけである。この 時期に気管・気管枝, 肺胞等に掠けるインフル エンザウイルス感染は如何であろうか。

また鼻粘膜にある粘液細胞も感染をうけるで あろうか(そうらしい所見もある)。インフル エンザウイルスがせん毛上皮細胞のどの辺から 排出されるのか等末解決の問題が多々ある。

同じような疑問をパラインフルエンザ，アデ ノ， RS ウイルス，ライノウイルス等について 問いただしてみるとほとんど解決されていな W。

ヒトにおけるビールス性呼吸器疾患の細胞, 
気食会報 -23 巻

あるいは組織レベルでの我くの知見はきわめて

微々たるものであることをのべてこの講演を終 りにしたい。

$$
\text { 文献 }
$$

1. Chanock, R.M.: Control of acute mycoplasmal and viral respiratory tract disease. Science 169 ;
248, 1970

2. Ebisawa, I., et al.: Immunocytologic study of nasal epithelial cells in influenza. Amer. J. Resp. Dis., 99 ; 507, 1969.

3. Tateno, I. et al.: Diagnosis of influenza by means of fluorescent antibody technique, Japan. J. Exp. Med., 32 ; 531, 1962.

\section{気管支造影剤}

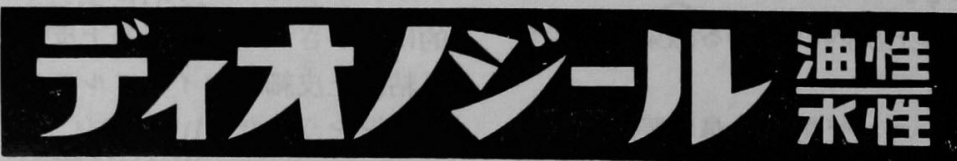

特長

-きわめて鮮明な影像が得られる

- 吸収がよく24時間後には局所から ほとんど消失する

一注入は容易で刺激作用を認めない

\section{包装}

油性・水性 $15 \mathrm{m \ell} 60 \mathrm{m \ell}$ バィアル入

\section{薬価基準}

（水性） $50 \% \quad 1 \mathrm{~m} \ell 39.00$ 円

（油性）60\% $1 \mathrm{m \ell} 39.00$ 円

\section{健保適用}

\section{赀造元 グラクソ不二薬品研究所 \\ 眨売促進 インターナショナル・トラシック・ルロス \\ 発克元鳥居薬品株式会社}

